
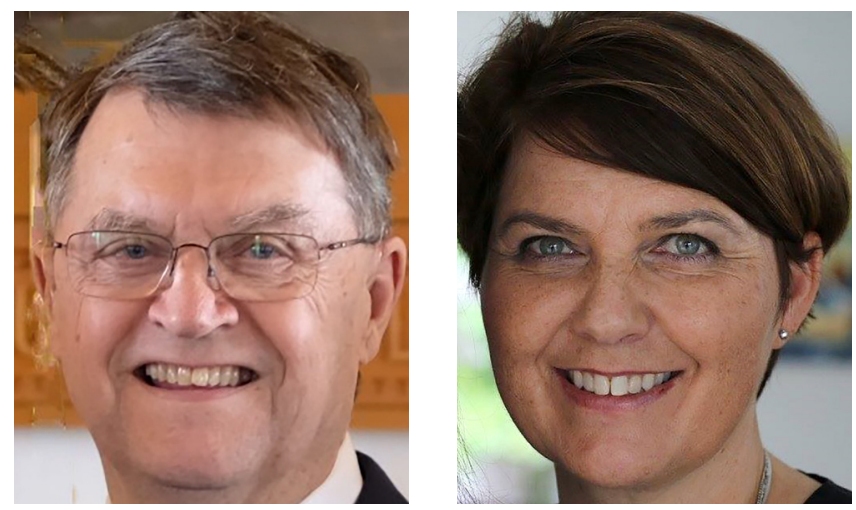

\title{
November Eight Four Two Three Tango This is Hornafjörður!
}

\section{Flugslys N8423T við Kambhorn \\ í Hornskriðum, Vestrahorni 10. ágúst 1998}

SVEND RICHTER, CAND. ODONT. MS. DÓSENT EMERITUS, TANNLAEKNADEILD HÁSKÓLA ÍSLANDS, RÉTTARTANNLAEKNIR, DVI, KENNSLANEFND RÍKISLÖREGLUSTJÓRA SIGRÍĐUR RÓSA VÍĐISDÓTTIR, CAND. ODONT. MS. LEKTOR, TANNLAEKNADEILD, HÁSKÓLA ÍSLANDS, RÉTTARTANNLAEKNIR, DVI, KENNSLANEFND RÍKISLÖREGLUSTJÓRA

NETFÖNG: svend@hi.is, srv2@hi.is, TANNLAEKNABLAĐIĐ 2021; 39(2): 23-30

doi:10.33112/tann.39.2.2

\section{ÁGRIP}

Prír pýskir feðgar komu til Íslands á einkaflugvél sinni, Piper PA-32-301 Saratoga, hinn 5. ágúst 1998. Peir dvöldu hér á landi og ferðuðust um til 10. ágúst pegar peir snéru heim. Fyrsti áfangi átti að vera Höfn, Hornafirði með stefnu á stefnuvitann INGO-VOR við Fagurhólsmýri og paðan á radíovitann HN-NOB. Flugmaðurinn hóf ekki aðflugið pegar komið var yfir radiovitann á Höfn, heldur hélt áfram stefnu til austurs og lækkaði flugið inn yfir fjöllin og flaug á klettavegg í Hornskriðum, Vestrahorni, par sem vélin splundraðist. Feðgarnir létust samstundis. Talið er að PIC/faðirinn hafi verið upptekinn í samskiptum við flugturn, á mati á aðstæðum og ákvarðanatöku, en eldri sonurinn hafi verið flugmaðurinn. Annar höfundur fór á vettvang ásamt rannsóknarstjóra flugslysa. peim til aðstoðar voru menn úr Flugbjörgunarsveit í Reykjavík. Aðstæður á vettvangi var erfiðar. Flakið var í brattri, lausri skriðu par sem erfitt var að athafna sig. Góðar tannlæknaskýrslur bárust frá pýskalandi. Vel gekk að bera kennsla á hina látnu sem byggðist fyrst og fremst á upplýsingum af tönnum.

Lykilorð: flugslys, Kambhorn, Hornskriður, tannlæknisfræðileg auðkenning 


\section{Meginmál}

Fjallað er um einkaflug priggja pýskra feðga til íslands í ágúst 1998. Faðirinn 45 ára læknir og eldri sonurinn 20 ára voru með flugmannsréttindi, yngri sonurinn var 12 ára. Flugvélin var með einkennisnúmer N8423T af gerðinni PIPER PA-32-301 Saratoga, einhreyfils einstjórnarflugvél (Single Engine Piston / SEP), vél sem tekur allt að 5 farpega auk eins flugmanns (Mynd1) (1).

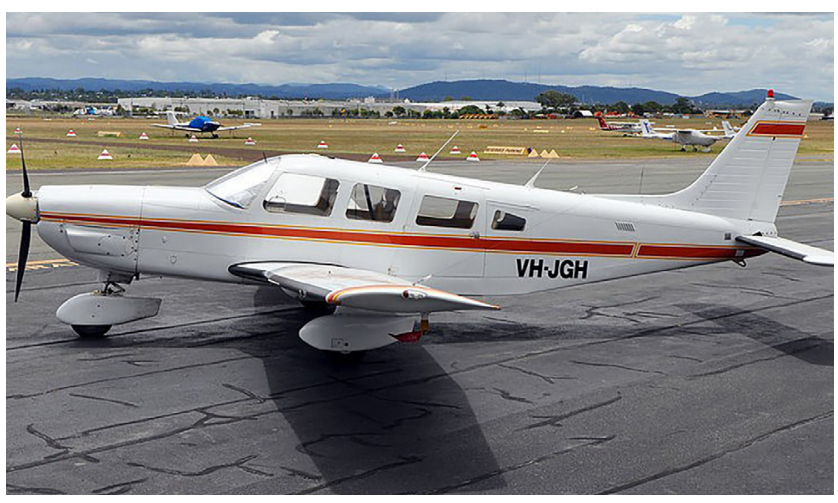

Mynd 1. Flugvél sömu gerðar og vél feðganna N8423T (2).

Figure 1. An aircraft of the same type as the father and son's N8423T (2).

Leið peirra lá frá Berlín 2. ágúst 1998 til Hannover og Sylt í pýskalandi, paðan til Kristiansand og Haugesund i Noregi. Í næsta legg var flogið til Leirvíkur á Hjaltlandseyjum. Til stóð að fljúga næst til Færeyja, en á fyrirhuguðum komutíma á Vágaflugvelli var veður óhagstætt, poka og ský niður í 200 fet. Pví var haldið áfram til Hornafjarðar par sem vélin lenti eftir 5 tíma og 54 mínútna flug. Eldsneyti var tekið á vélina og fluginu haldið áfram til Reykjahlíðarflugvallar. Við lendingu losnaði hægri hjólbarði og stöðvaðist vélin pvert á braut $(3,4)$. Dekkinu var skipt út daginn eftir og var vélinni flogið til Akureyrar og í framhaldi til Reykjavíkur. Í Reykjavík keypti skráður flugstjóri, PIC (pilot-in-command), fullkomið „AlP Ísland” (flughandbók par sem er að finna upplýsingar um íslensk flugleiðsögukerfi, flugvelli og aðflug að peim) (5). Pann 8. ágúst var vélinni flogið til Ísafjarðar og síðan til Patreksfjarðar, par sem feðgarnir prír tjölduðu í nágrenni bæjarins $(6,7)$.

Að morgni 10. ágúst var undirbúið flug til baka frá Reykjavík til Pýskalands með flugbjónustunni Flight Services Inc. Faðirinn sem kynnti sig sem flugstjóra, PIC fyrirhugaðs flugs, fékk upplýsingar um veðurfar á fyrirhugaðri leið til Hornafjarðar og áfram til Shetlandseyja um Vága. Hann fékk möppu með veðurspá fyrir fyrirhugaða leið frá Veðurstofu Íslands. Enn fremur ræddi hann í síma við vakthafandi starfsmann á Veðurstofu um veðurspánna. PIC lagði síðan fram flugáætlun fyrir fyrsta legginn til Hornaafjarðar. Lagt yrði af stað frá Reykjavík með stefnu á stefnuvitann INGO-VOR við Fagurhólsmýri og paðan á radióvitann HN-NOB við Hornafjörð. Flogið yrði í 7.000 feta hæð í hefðbundnu IFR flugi (blindflugi). Áætlaður flugtími var gefinn 1:30 klst og eldsneytispol 8:00 klst., varaflugvöllur var Egilstaðir (Mynd 2) (7, 8).

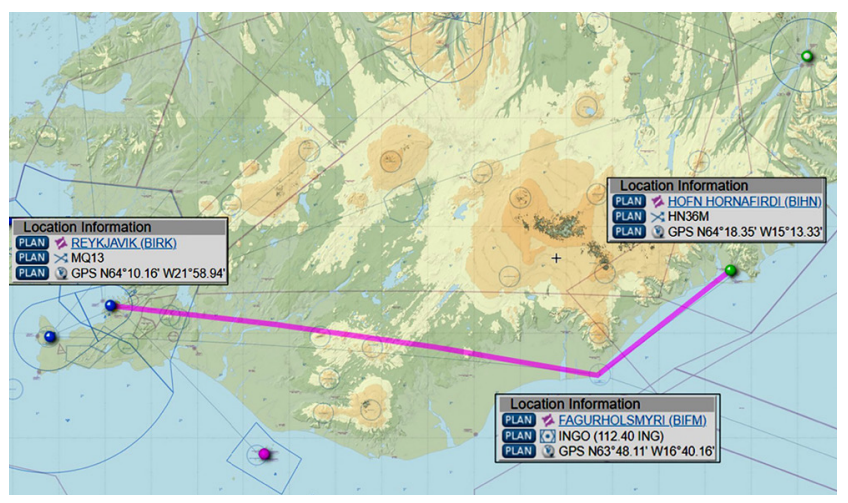

Mynd 2. Flugáætlun N8423T til Hornafjarðar um Ingólfshöfða (INGO), kort gerð i SkyVector Aronautical Chart Plan: Flight Plan (9) Figure 2. Flight plan N8423T to Hornafjordur via Ingólfshöfði (INGO), chart done in SkyVector Aronautical chart Plan: Flight Plan (9).

Flugvélin fór í loftið frá flugbraut 14 klukkan 10:49. Eftir flugtak átti PIC í nokkrum vandræðum með að koma vélinni i stefnu á INGO, heldur stefndi á radíovitann (NDB) í Reykholti, Borgarfirði. Aðflugsstjórn í Reykjavík tókst að leiðbeina PIC í stefnu á INGO. Flugið gekk nokkuð vel til Hornafjarðar, vélin fékk leyfi til að breyta af stefnu vegna skýja og lækkun á flughæð vegna ísingar. PIC hafði öll samskipti sjálfur í fluginu. Á sömu flugleið til Hornafjarðar um INGO var hraðfleygari rússnesk tveggja hreyfla vél YL-KAD af gerðinni Antonov AN-28. Pegar vélarnar nálguðust Hornfjörð föru pær úr radarsviði flugumsjónar í Reykjavík og voru pær beðnar að vera í sambandi við flugturn á Hornafirði, en par er engin radarvöktun. Par sem YL-KAD var á undan N8423T til Hornafjarðar var henni gefin aðflugs- og lendingaheimild og lenti vélin eins og til stóð á braut 18 (Mynd 4) (7).

PIC (faðirinn) tilkynnti kl. 12.41 að peir væru yfir radiovitanum HN á Höfn í aðflugslínu að flugvelli. Ljóst er að vélin var í rangri aðflugstefnu. Vélin átti samkvæmt stefnuvita að fljúga í stefnu 03, nánast í hánorður að braut 36, en hélt norðaustur í stefnu $30^{\circ}$, nánast í beinni stefnu í framhaldi frá INGO til radiovitans HN (Mynd 4), í eina og hálfa mínútu í 7-8km í 3.200 fetum í stefnu á fjöllin 


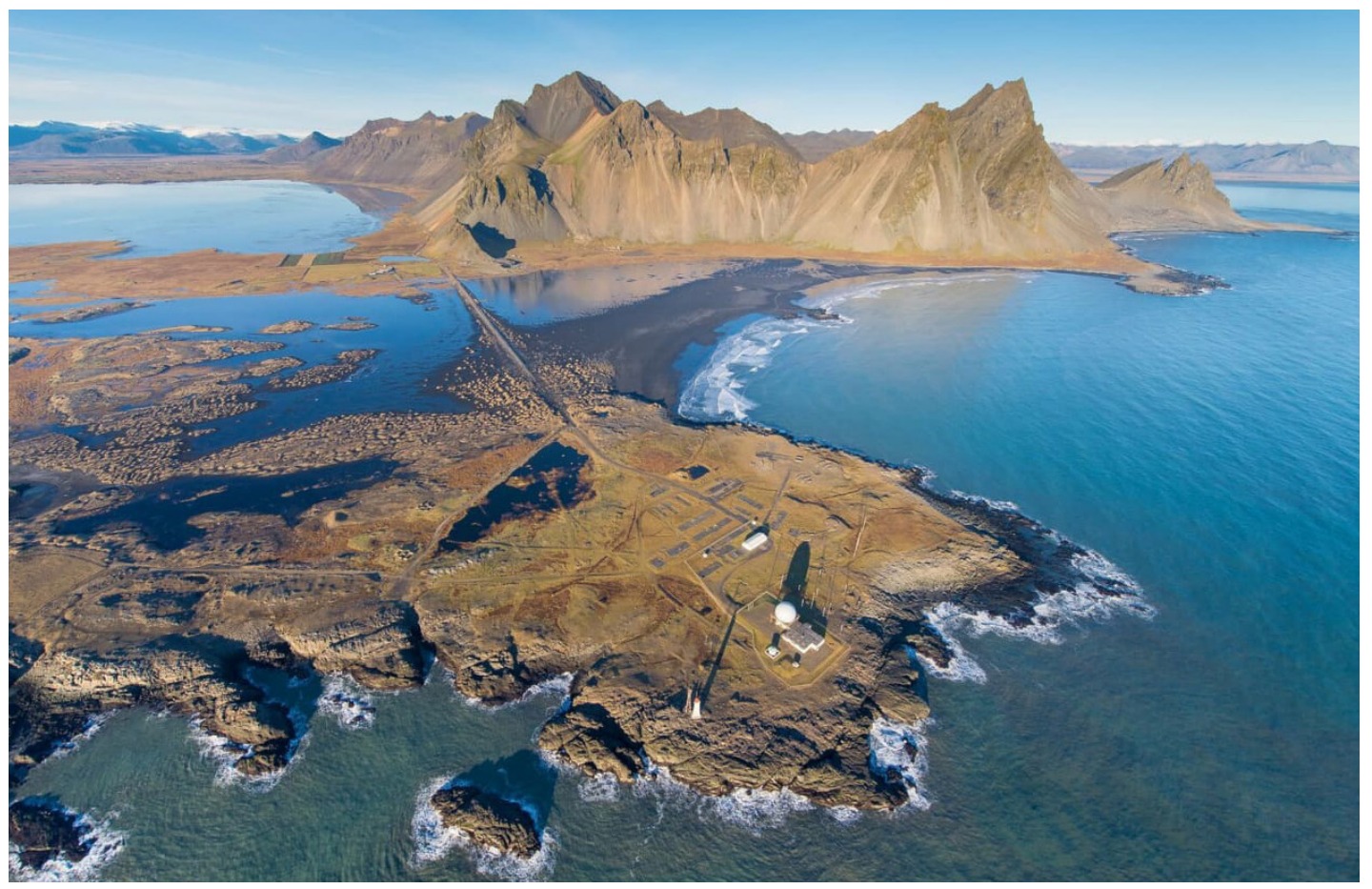

Mynd 3. Hið tilkomumikla Vestrahorn og Kambhorn séð frá radarstöðinni á Stokksnesi (12).

Figure 3. The impressive mountain Vestrahorn and Kambhorn seen from the radar station at Stokksnes (12).

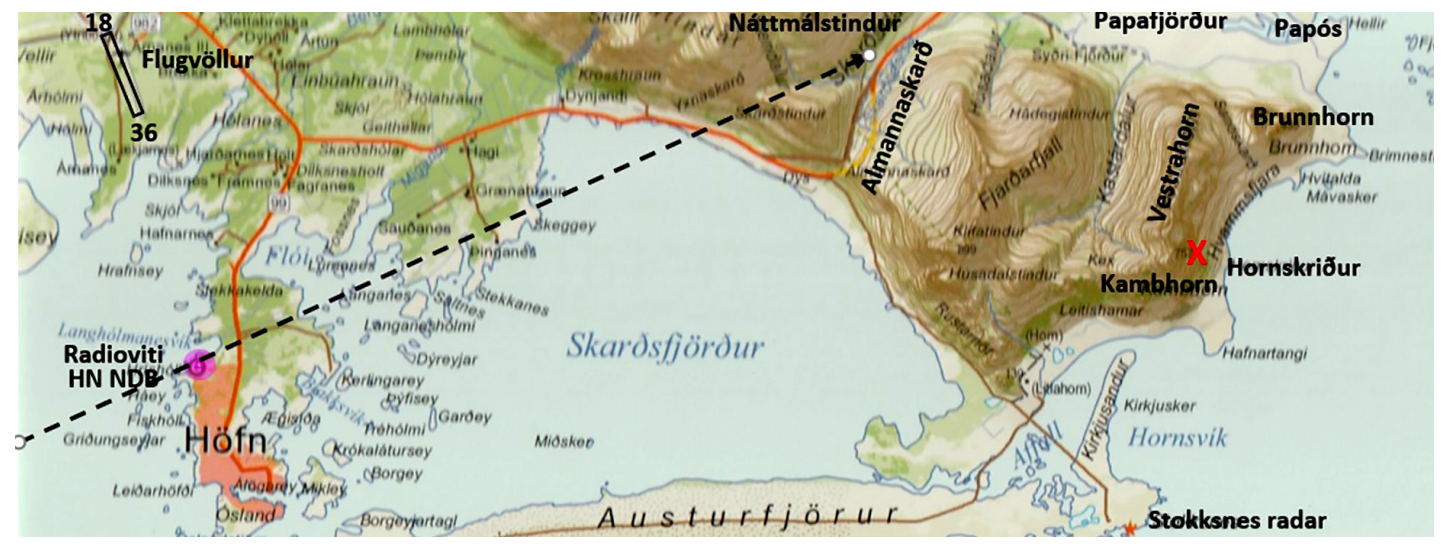

Mynd 4. Talið er að i stað pess að taka stefnu norður að flugbraut 36 frá Non-Directional Beacon, hafi hún flogið beint áfram norðaustur til fjalla par til hún skall á klettavegg við Hornskriður í Vestrahorni (8).

Figure 4. It is believed that instead of taking direction north to runway 36 from the Non-Directional Beacon, it flew straight ahead northeast to the mountains until it hit the mountain cliff at Hornskriður in Vestrahorn (8).

í blindflugi, pví skýjahæð var í 300-500 fetum. Í síðasta radarspori við Náttmálstind í Almannaskarði var hún byrjuð í hægri beygju. Eftir pað náđi loftnet frá Stokksnesi ekki til vélarinnar vegna skugga af fjöllum.

Síðustu radarmerki benda til að hún hafi verið byrjuð í hægri beygju yfir Papafjörð, fyrir Papós og inn skarðið milli Brunnhorns og Vesturhorns, en einnig er mögulegt að hún hafí farið fyrir Brunnhornið og síðan stefnt beint á klettavegg í Hornskriðum í Vestrahorni (Mynd 4). Sjálfvirkur neyðarsendir í vélinni fór í gang pegar vélin splundraðist og sendi út í um 10 mínútur. Pá var enginn gervihnöttur eða tæki tiltæk til að geta staðsett hana nákvæmlega. Frá pví að flugmaðurinn tilkynnti um aðflug á flugvellinum á Höfn og par til vélin fórst er talið að liðið hafi í mesta lagi prjár til fjórar mínútur $(3,7,8)$.

Hjálparsveitarmenn fundu flak vélarinnar um hádegisbil 11. ágúst, daginn eftir slysið. pá höfðu um 400 leitarmenn og prjár pyrlur tekið pátt í leitinni sem beindist fyrst og fremst að fjallgaðinum austan við Höfn, en leitarskilyrði voru slæm (10). 
Fulltrúar frá Rannsóknarnefnd flugslysa og Kennslanefnd Ríkislögreglustjóra flugu síðdegis 11. ágúst til Hornafjarðar (Mynd 5). Á tveggja tíma kvöldfundi á lögreglustöð með fulltrúa sýslumanns, lögreglu og félögum úr Flugbjörgunarsveit kom fram að flak vélarinnar væri fundið hátt í Hornskriðum sem er hæst um 600 m hátt fjall með klettabelti i Vestrahorni og uppganga mjög erfið i $60^{\circ}$ skriðum. Skyggni væri takmarkað og stutt í myrkur.

Lagt var á slysstað fyrripart nætur næsta dag eftir nokkra klst. hvíld. Auk Svend Richter, föru á vettvang Skúli Jón Sigurðsson frá Rannsóknarnefnd flugslysa. Peim til aðstoðar voru 14 félagar úr Flugbjörgunarsveit Reykjavíkur og lögregla frá Höfn.

Flak vélarinnar var staðsett i djúpu pröngu gili i klettabelti Hornskriða u.p.b. $14.5 \mathrm{~km}$ austur af Hornafjarðarflugvelli. Efri

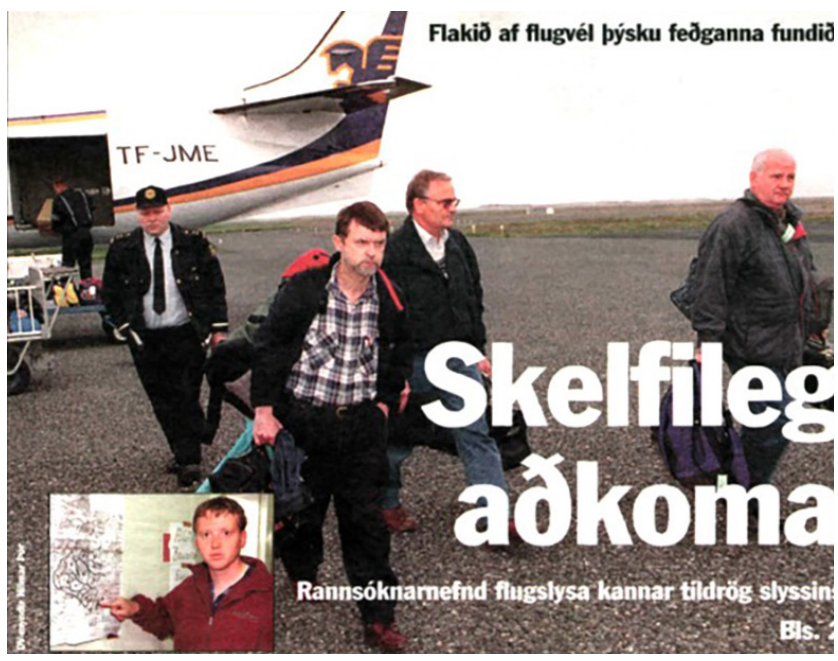

Mynd 5. Fulltrúar rannsóknarnefndar flugslysa og DVI kennslanefndar á Hornafjarðarflugvelli siððla dags 11. ágúst 1989 (11).

Figure 5. Members of aircraft accident investigation board and DVI, disaster victim identification, at Hornafjordur airport late August 11, 1989 (11). hluti gilsins er um 15 m á breidd, en sá neđri mun víðari um 500 m, í um 300 m hæð frá sjó, en efsti hluti gilsins i 600 m yfir sjó. Halli í botni gilsins var um $45^{\circ}-50^{\circ}$. Botninn var mjög óstöðug laus skriða. Vélin skall í vesturhluta klettaveggsins fyrir ofan gilið í um 600 m hæð frá sjávarmáli, 15-20 m frá fjallsbrún. Hæð Kambhorns, hæsta hluta Vestrahorns er 755 m. Við árekstur við fjallið splundraðist vélin, kviknaði í henni og féll niður gilið (8). Skúli Jón einbeitti sér að pví sem snéri að fluginu, árekstur vélar, vélarhluta og pappíra sem tengdust fluginu sem voru á víð á dreif (Mynd 6). I brunnu flakinu voru lík mannanna priggja og lék ekki vafi á að mennirnir hafi látist samstundis, líklegt er að peir hafi aldrei séð klettavegginn par sem hann var hulinn skýjum (3).

Hlutverk Svend var að skrá hina látnu, staðsetningu í flaki og búa til flutnings. Jafnframt að tryggja að líkamsleifar

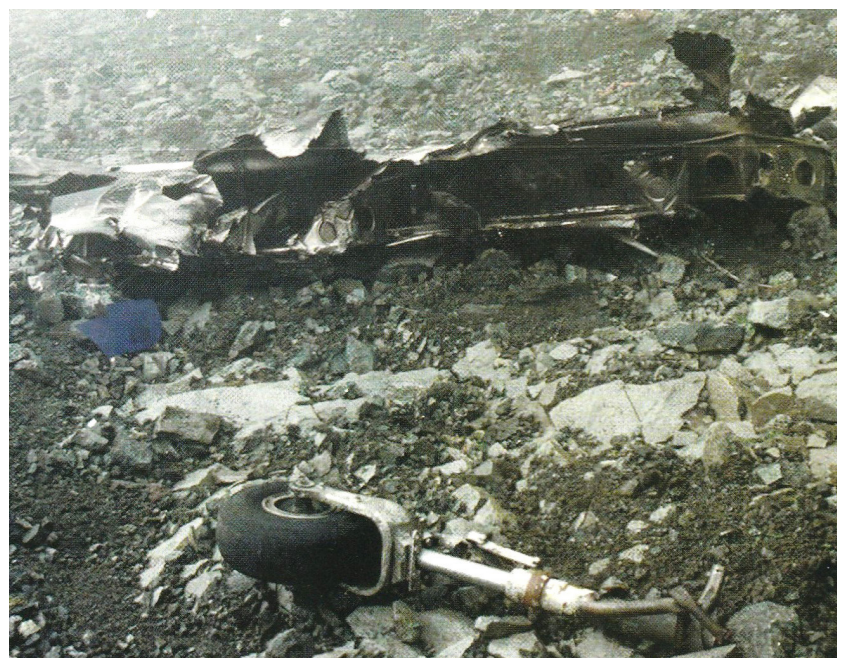

Mynd 6. Brak úr vélinu nokkuð ofar í fjallinu en par sem skrokkur hennar fannst með hinum látnu.

Figure 6. Parts from the plane somewhat higher up in the mountain than where the fuselage was found with the deceased.

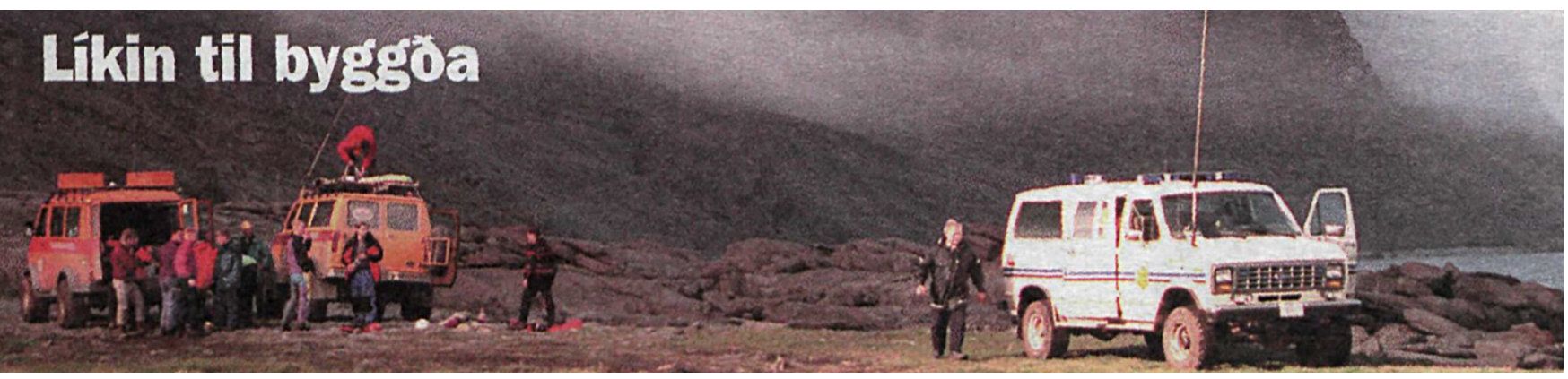

Mynd 7: Jarðneskar leifar pýsku feðganna komnar niður af Vestrahomi. Á myndinni undirbúa björgunarsveitarmenn, menn frá rannsóknarnefnd flugslysa, kennslanefnd ríkislögreglustjóra og lögregla flutning til Hafnar og paðan til Reykjavíkur (12).

Figure 7. The human remains down from the Vestrahorn. In the picture, rescue squads, representatives from the Aircraft accident investigation board, DVI commision Iceland and the police preparing to move them to Höfn and then to Reykjavik (12). 


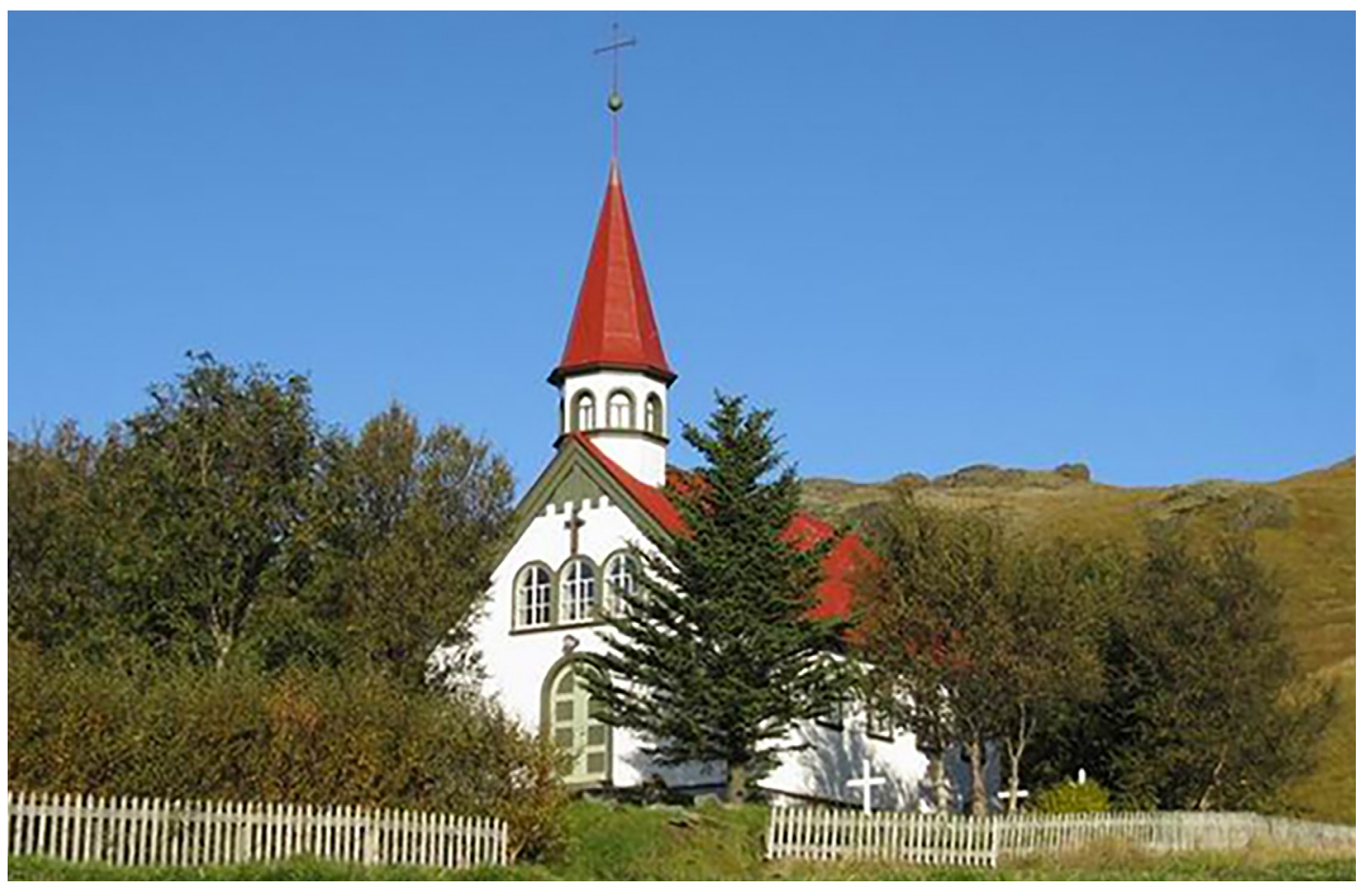

Mynd 8. Stóra-Núpskirkja og kirkjugarður (15).

Figure 8. The church Stóra-Núpskirkja and cemetery (15)

væru ekki skildar eftir á vettvangi. Aðstaða var hin erfiðasta par sem flakið var í mjög lausri skriðu og erfitt að fóta sig. Björgunarsveitarmenn aðstoðuðu við pað verk sem reyndi mjög á pá. Pessir ungu menn voru duglegir fjallamenn en höfðu aldrei lent í slíkum aðstæðum, að aðstoða við að koma illa brunnum líkamsleifum í líkpoka. I framhaldi voru jarðneskar leifar pýsku feðganna fluttar niður úr fjallinu. Leiðangurinn á fjallið tók rúmar 12 klukkustundir. Á Mynd 7 undirbúa björgunarsveitarmenn, menn frá rannsóknarnefnd flugslysa, DVI kennslanefnd og lögregla flutning til Hafnar en paðan var farið með jarðneskar leifar feðgana til Reykjavíkur (12).

Pegar komið var til Hafnar fóru Skúli Jón og Svend í flugturn og hittu Guðlaug Kristinsson, reyndan flugumferðarstjóra á eftirlaunum sem leysti af í sumarleyfi og Skúli Jón pekkti af góðu einu. Hann sagði að rétt áður en flugvél pjóðverjanna átti að lenda hafi rússnesk tveggja hreyfla smáflugvél (YL-KAD) lent á vellinum á braut 18 . Hún lenti kl. 12.41 og á sama tíma var turn í sambandi við pjóðverjana. Eftir að hann hafði gefið leiðbeingar um aðflug og lendingu slitnaði samband við hana. Hann reyndi kallmerki vélarinnar, Two Three Tango (prír síðustu stafir í einkennismerki vélar N8423T) og síðan November Eight Four Two Three Tango. This is Hornafjörður! pegar engin svör bárust i 3 mínútur, gerði hann sér strax grein fyrir pví að vélin hafði farist og lét flugumsjón í Reykjavík vita. Í hans huga var atvikið skýrt, hann hefði áđur lent í svipuðu atviki. Strax voru kallaðar út björgunarsveitir.

Ekki liggur fyrir af hverju flugmaður vélarinnar beygði ekki til aðflugs að flugvelli, pegar komið var yfir radíovitann við Höfn. Í skýrslu rannsóknarnefndar flugslysa eru leiddar líkur að pví að eldri sonur pýska læknisins hafi stjórnað vélinni og faðirinn verið upptekinn við fjarskipti. Pessi skoðun byggir á staðsetningu hinna látnu í flugvélaflaki. Faðir og eldri sonur sátu i fremstu sætum, en sá yngri i sæti aftan við pá, en sérstaklega upplýsingar fegnar úr réttarkrufningu, en eldri sonurinn var handarbrotinn. Peir voru báðir með einkaflugmannsréttindi og sögðust vera með 700 flugtíma hvor. Peir höfðu báðir réttindi til blindflugs en talið er að peir hafi ekki haft mikla reynslu í blindflugsaðflugi við aðstæður eins og voru í Hornafirði á peim tíma sem vélin fórst (8).

Hver er sennileg skýring á flugslysinu? Talið er að flugvélinni hafi verið flogið á stjálfstýringu megnið af leiðinni til Hornafjarðar. PIC/faðirinn sá um samskiptin og var upptekinn við pau við flugturn HN um val á stefnu á flugbraut, 18 eða 36, á mjög viðkvæmum tímapunkti pegar peir flugu yfir radiovitann við Höfn, par sem hefja átti aðflug að braut. Sennilegt er flugmaðurinn/eldri sonur sem stjórna átti tækjum vélar hafi ekki tekið strax ákvörðum yfir 
radiovita $\mathrm{HN}$ að fylgja opinberlega útgefnum fyrirmælum um að hefja rétt aðflug að flugvelli. Flugmaður var ekki vanur blindflugi (8).

peir höfðu áður komið til Íslands, en pá millilentu peir í Reykjavík pegar peir voru að ferja vélina frá Bandaríkjunum til pýskalands. Faðirinn sagðist einnig hafa komið til ĺslands sem ungur maður og heillaðist af land og pjóð (13).

Útför feðgana pýsku fór fram hér á landi og hvíla peir í Stóra-Núpskirkjugarði í Skeiða- og Gnúpverjahreppi sem er í Hrunaprestakalli í Suðursprófastsdæmi (14). Par hafði faðirinn óskað eftir að verða jarðsettur eftir sinn dag. Honum varð að ósk sinni.

\section{Kennsl borin á hina látnu}

Réttarkrufning fór fram á Rannsóknarstofu háskólans í meinafræði. Gunnlaugur Geirsson réttarlæknir, Sigríður Rósa Víðisdóttir og Svend Richter réttartannlæknar og lögregla frá tæknideild sáu um rannsóknina. Tannlæknisfræðilegar upplýsingar fengust frá Pýskalandi, Der Polizeipräsident in Berlin, Landeskriminalamt 131. Unnið var eftir leiðbeiningum DVI Interpol um auðkenningu látinna (16) og eyðublöðum pess $(18,19)$. Aldursgreiningar voru gerðar samkvæmt aðferðum Kullman (20), Liversidge (21), Mincer (22) og Schour og Massler (23). Niðurstaða réttartannlækna var eftirfarandi:

\section{Auðkenning 1}

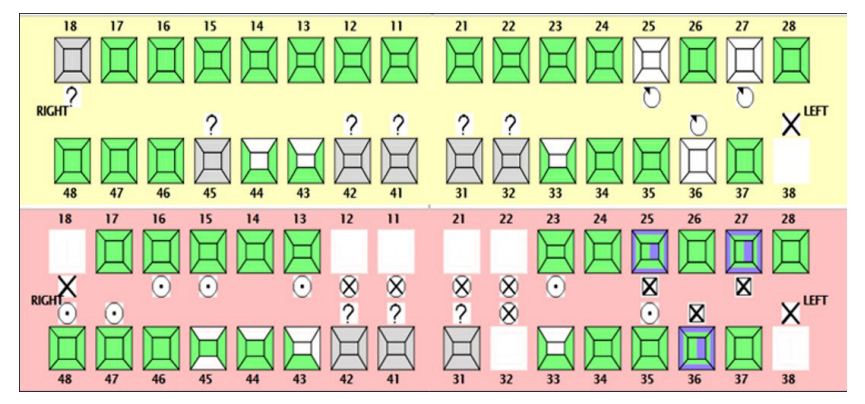

Mynd 9. Auðkenning 1, skematísk mynd úr Plassdata (24), ante mortem og post mortem tannkort eru borin saman.

Figure 9. Identification 1, schematic diagram from Plassdata (24),

ante mortem and post mortem odontograms are compared.

Faðir. Fæðingadagur 22.10.1952.

Postulínskrónur á tönnum: 17, 16, 15, 14, 13, 23, 24,

$26,28,37,35,34,46,47,48$

Milliliðir í brúm: 25, 27, 36

Tönn vantar: 38

Fyllingar í tönnum: 44, 33

\section{Auðkenning staðfest}

\section{Auðkenning 2}

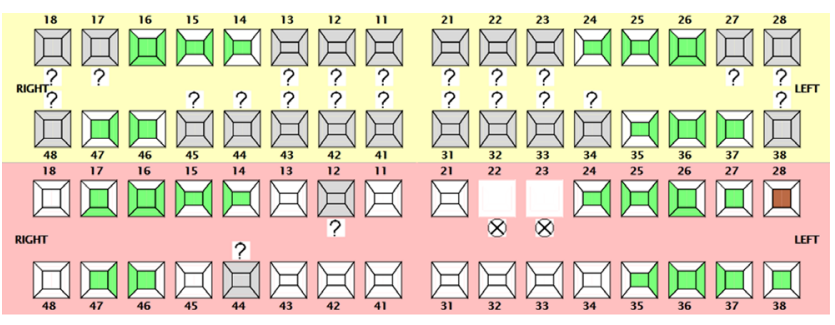

Mynd 10. Auðkenning 2, skematísk mynd úr Plassdata (23), ante mortem og post mortem tannkort eru borin saman.

Figure 10. Identification 2, schematic diagram from Plassdata (23), ante mortem and post mortem odontograms are compared.

Eldri sonur. Fæðingadagur 30.09.1978

11 postulínsinnlegg í tönnum: 16, 15, 14, 24, 25, 26, $37,36,35,46,47$

Aldursgreining af endajöxlum

\section{Auðkenning staðfest}

\section{Auðkenning 3}

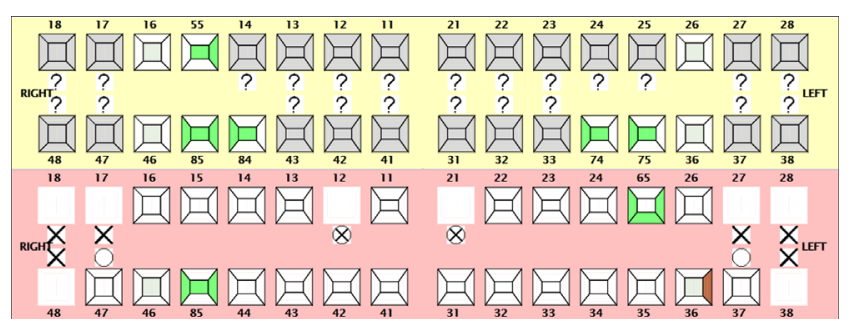

Mynd 11. Auðkenning 3, skematísk mynd úr Plassdata (23), ante mortem og post mortem tannkort eru borin saman.

Figure 11. Identification 3, schematic diagram from Plassdata (23), ante mortem and post mortem odontograms are compared.

Yngri sonur. Fæðingadagur 26.08.1986

Fylling í tönn: 85

Skorufyllur í tönnum: 36, 46

Aldursgreining af proska og framkomu tanna

\section{Auðkenning möguleg}




\section{HEIMILDIR}

1. Plane PhD. https://planephd.com.

2. Flickr. Mynd Robert Frola. https://www.flickr.com/photos/robertfrola/9065084527/.

3. Árvakur hf. Leitarsvæðið erfitt yfírferðar og skyggni slæmt. Morgunblaððð 13 ágúst 1989: 4.

4. Board AAI. Aircraft accident report. M-07298/AIG-24. 1989.

5. ISAVIA. Flugmálahandbók Íslands (AIP). https://wwwisaviais/fyrirtaekid/cforflugsupplysingar/flugmalahandbok-aip.

6. Flight Safety Foundation wfoAW. Hamburger Abendblatt 12 August 1998.http:// registry.faa.gov/aircraftinquiry/NNum_Results.aspx?omni=Home-NNumber\&nNumberTxt=8423T.

7. Sigurðarson SJ. Ársskýrsla Rannsóknarnefndar flugslysa (RNF). 1989.

8. Board AAI. Aircraft Accident Report, M-07298/AIG-24. 1989.

9. SkyVector Aronautical Chart Plan: Flight Plan https://skyvectorcom/.

10. Árvakur hf. Morgunblaðið 12 ágúst 1998: 4.

11. Frjáls fjölmiðlun ehf. DV 12 ágúst 1998: 1.

12. Ríki Vatnajökuls ehf. Visit Vatnajokull. https://visitvatnajokull.is/how-to-get-to-thefamous-vestrahorn/.

13. Frjáls fjölmiðlun ehf. DV 13 ágúst 1998: baksiða. DV-mynd Júlia Imsland

14. Árvakur hf. Morgunblaððð 11 ágúst $1998: 4$.
15. Kirkjugarðasamband Íslands. gardur.is. https://www.gardur.is/leit_einfalt_c.php.

16. Skeiða- og Gnúpverjahreppur. https://www.skeidgnup.is/efni/st\%C3\%B3ran\%C3\%BApskirkja S-oG.

17. Interpol. INTERPOL Disaster Victim Identification Guide. .file:///C:/Users/Svend/ AppData/Local/Temp/MicrosoftEdgeDownloads/82ab4400-4777-4183-8dafe80488845fb2/18Y1344\%20E\%20DVI_Guidepdf.

18. INTERPOL DVI Form - Unidentified Human Remains.

19. INTERPOL DVI Form - Missing Person.

20. Kullman L. Accuracy of two dental and one skeletal age estimation method in Swedish adolescents. Forensic Sci. Int. 1995;75(2-3):225-36.

21. Liversidge HM. Timing of human mandibular third molar formation. Ann Hum Biol. 2008;35(3):294-321.

22. Mincer HH, Harris EF, Berryman HE. The A.B.F.O. study of third molar development and its use as an estimator of chronological age. J Forensic Sci. 1993;38(2):379-90.

23. Schour I, Massler M. Development of human dentition. J Am Dent Assoc 1941;20:379427.

24. KMD PlassData DVI. Computerized identification of disaster victims and missing persons. https://www.kmd.net/solutions-and-services/solutions/kmd-plassdata-dvi

English Summary

\title{
November Eight Four Two Three Tango. This is Hornafjörður! Aicraft accident N8423T near Kambhorn at Hornskriður, Hornafjörður, Iceland. 10th August 1998
}

\author{
SVEND RICHTER, DDS, MSC, ASSOCIATE PROFESSOR EMERITUS \\ FACULTY OF ODONTOLOGY, UNIVERSITY OF ICELAND. FORENSIC ODONTOLOGIST, DISASTER VICTIM \\ IDENTIFICATION, NATIONAL COMMISSIONER OF POLICE \\ SIGRIDUR ROSA VIDISDOTTIR, DDS, MSC, ASSISTANT PROFESSOR \\ FACULTY OF ODONTOLOGY, UNIVERSITY OF ICELAND. FORENSIC ODONTOLOGIST, DISASTER VICTIM \\ IDENTIFICATION, NATIONAL COMMISSIONER OF POLICE
}

ICELANDIC DENT J 2021; 39(2): 23-30

doi:10.33112/tann.39.2.2

A German father with his two sons arrived in Iceland on their private plane, Piper PA-32-301 Saratoga, on 5th August 1998. They traveled around until 10th August, when they returned home. The first trip was to be Höfn, Hornafjörður with a direction to the INGO-VOR, a high frequency omnidirectional radio range at Fagurhólsmýri and HN-NDB, a non-directonal beacon near Höfn. When over HN-NDB, the pilot did not start the approach to the airport but continued heading east and lowered the flight into the mountains, flew on a rock wall in Hornskriður, Vestrahorn and shattered. The father and sons died immediately. One of the authors went to the scene together with the director of the air accident investigation. They were assisted by some young men from the air rescue squad and the police. The expedition in the mountain took about 12 hours and the conditions were all the most difficult in steep slides of loose gravel and rocks. It must be considerd very likely that at the final stage of the flight, the workload aboard the aircraft was distributed as such, that the PIC/father was handling communication, evaluating the conditions and making decisions and the older son was the pilot flying. Good dental records were received from Germany. The identification of the dead was successful, mainly based on dental information.

Keywords: aircraft accident, N8423T, Kambhorn, Hornskriður, forensic dental identification Correspondence: Svend Richter - svend@hi.is, Sigríður Rósa Viðisdóttir - srv2@hi.is 